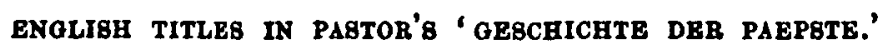

In his review of the above work in July last (Enaurs Historical Revrew, xii. 562), Mr. Garnett mentions some misreadings of English titles, which in one instance he has rectified; for I think there can be no doubt that the reading 'Cicestren' for 'Cuestion' is the right one. But the other two which he leaves unsolved seem to me almost as little open to doubt. 'Burgoynye' as the title of a nobleman can be nothing but 'Burgavenny,' the usual form, in those days, for Abergavenny. And as to dom. Dunbendii, regni Angliae Cameraito, the case is equally clear. For though it is true, us Mr. Garnett remarks, that the office of high chamberlain of England was hereditary in the De Veres, earls of Oxford, the office of ling's chamberlain was quite a different thing; and it is manifest that the address should have been not regni but regis Angliae Camerario. Now the king's chamberlain from 1495 to 1508 was Giles, lord Daubeney, whose title has been here misread Dunbendii. Jaser GaIRdarer.

\title{
A LETTER DESCRIBING THE DEATH OF GENERAL WOLTE.
}

The following letter, now in the possession of Mrs. Douglas-Willan, adds, I think, another account of the death of General Wolfe to those already printed. The writer, James Henderson, who had joined the Louisberg grenadiers as a volunteer, is mentioned by Parkman ('Montcalm and Wolfe,' ii. 296) and others as having assisted Wolfe to the rear when wounded.

W. A. J. Archbold.

Honourd Sir.-I now have the Pleasure of Writing to you from Quebeck Which Place is in His Britanick Majesteis Posesion. As to Our Proceding During the Seige I Shall not Trouble you With As you Will See It At Large in the Publick Papers. But Will Aquaint you With My own Procedings Which I hope Will Give you Satisfacition. Notwithstanding All the Expedition I Could Use it Was the 16th of April Before I Arrived At L[ouis]burg. On my Arivell there I found that our Regt Wes Not to go Up the River. But upon Mr Wolfe's Arrivel he Brought An Order for the Graniders of the Garrison to joyn him Which Graniders, Consisting of three Companys, Was Formed into A Batalion under the Command of Colnel Murray. I then Applied to Gen. Whitmore for Liberty to go With our Graniders, Which he Granted me And Rocomended me Strongly to Genarel Wolfe. There Was no service During the Campain that Required Courage And Ressalut(i)on But

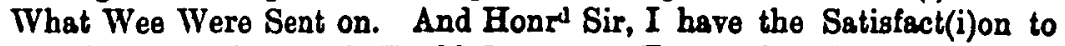
Aquaint you that God Enabled me on Every Ocassion to Do my Daty to the Satisfaction of All My Commanding Officers And in Particular on that Ever Memorable Day the 19th of Sept. When the two Armys Wes Drawn up, in Line of Battle Within A Bmall Distance of Each Other. Our Company of Gran" Was the Right of the Line Upon the Genar[el's] viewing in the Possion of the two Armys he took Notice of A Small Rissing Ground Between our Bight \& the Enimeys Lefi, Which Consailed there Motions from Us on that Quarter Upon 
Which the Gener' Did me the Honour to Detech me With a fow Graniders to take Possion of that Ground And Maintain it to the Last Eextremety Which I Did. Till Both Armys Was Lingaged And then the Genr' Come to Bfe And Took his Post By me. But Oh, How Cen I toll you My Dr Sir, Tears flow from Eyes Whill I Write. That Grest, that Ever Memorable Mian Whos Loss Can never be Enough Regreted WWa Scerce A Moment With me till he Receved his Fatal Wound. I my Self Receved At the same time two Wounds for I Was Close to him, one in the Right Shoulder \& one in the thigh. But My Consern for him Was so Great that I Did not At that Time think of thom. When the Genr Receved the Shot I Caut Hold of him And Carried him of the Feild, he Walked About one Hundred yords And then Beged I Would Let Sit Down, Which I Did. Then I Opened his Bresst, And found his Shirt full of Blood At Which he Smiled And When he Seen the Distress I Was In, My Dear, Sidd he, Dont Grive for me, I Shall Be Happy In a Ferv Minutes. take Care of your Self As I see your Wounded. But Tell me 0 tell me How Goes the Battle their, Just then Came some Officers Who told him that the Freinch had civen Ground \& Our trooups Was pursuing Them to the Walls of the town, he Was then Lying in my Arms Just Expirin That Grest Mran Whos Sole Ambition Was bis Country Glory Raised himself up on this News And Smiled in my Face. Now, Said be, I Die Contented, from that Instant the smile never Left his Face till he Deided. I thought in him I had Lost All my Intrest But It Plessed God to Ferse me up Friends in All the Survifing Gen' Officers, And in Particular in Gen. Monction Who, upon his First Taking the Commend, Inquired for the Volinter that Distinguished him Self So Much on the $18^{\text {th }}$ Septr With Gen. Wolfe As he thought it A Duty Incombsnt on him in Honour to Gen. Wolfe's Memory to Propide for that Gentlemen. And In A Few Days he sent me Bly Commission By Colnel Welsh Who Is Mif Col. in the $28 \mathrm{Reg}^{\mathrm{t}}$ Conmenced By Gev. Bragg Which is one of the Finest Regt in the Service, And What Gives me the Grestest Plessure is that I Am Particularly Liked By Both My Col. \& Major. We are Single Officers that is, only one Livetenant to A Compsny And Out of Any Danger of A Breach. I Belive At the Opning of the Next Campain I Shall be Neir the Hesd of the Ensigns As their is A Great Bifany of Our Officers Goiing out of the Regt that Was Wounded Dr. Sir I Belive It Will Be Bcarce Possable for you to Read this, But you Must Excuse me As it is With Great Pain I Now Write As the Wound in my Arm is Not ye[t . . . . Hon Hir, I thought Nothing Should Excuse Me fr. ... Duty to you And my Friends At Home. Dr Sir . . . this Reaches you Be so Kind As to Acquaint my $D^{r}$... And Sister Vith my Good Fortune And take My Ex. . . . . Writing to them in Particular. My $D^{r}$ Sir I beg . . . Write to Me By the first Ships that Comes out. . . . Aa Nothing in the World Will Give Biore Pl. . . . Hear What Situacion my Dear Mother \& Sister . . . . Wife, I Am, Bly Dr Hon Sir, With MIy Sincere Love To All Bly Friends, your Ever

Loving Nephew, Ja Henderson.

P.S.-My Dr Sir, I must Again Beg that you Will Write to Me And Direct to me Ensign in the 20th Begt At Quebect. 